Published as: Geobiology. 2009 January ; 7(1): 21-24.

\title{
Phototrophic $\mathrm{Fe}$ (II) oxidation in an atmosphere of $\mathrm{H}_{2}$ : implications for Archean banded iron formations
}

\author{
L. R. CROAL ${ }^{1}$, Y. JIAO ${ }^{4}$, A. KAPPLER ${ }^{5}$, and D. K. NEWMAN ${ }^{1,2,3}$ \\ 1 Department of Biology, Massachusetts Institute of Technology, Cambridge, MA 02139, USA \\ 2 Department of Earth, Atmospheric and Planetary Sciences, Massachusetts Institute of \\ Technology, Cambridge, MA 02139, USA \\ ${ }^{3}$ Howard Hughes Medical Institute, Massachusetts Institute of Technology, Cambridge, MA 02139, \\ USA \\ ${ }^{4}$ Physical and Life Science Directorate, Biology and Bioscience Division, Lawrence Livermore \\ National Laboratory, Livermore, CA 94550, USA \\ ${ }^{5}$ Center for Applied Geoscience, University of Tübingen, Tübingen, Germany
}

\begin{abstract}
The effect of hydrogen on the rate of phototrophic Fe(II) oxidation by two species of purple bacteria was measured at two different bicarbonate concentrations. Hydrogen slowed Fe(II) oxidation to varying degrees depending on the bicarbonate concentration, but even the slowest rate of $\mathrm{Fe}$ (II) oxidation remained on the same order of magnitude as that estimated to have been necessary to deposit the Hamersley banded iron formations. Given the hydrogen and bicarbonate concentrations inferred for the Archean, our data suggest that Fe(II) phototrophy could have been a viable process at this time.
\end{abstract}

\section{INTRODUCTION}

Reconstructing the evolution of metabolism is a stimulating endeavor, yet riddled with challenges. Various approaches have been used in this pursuit, all of which have their limitations. For example, molecular biomarkers provide a link to specific time intervals in Earth history, but are only as valid as they are functionally linked to the metabolisms they are thought to represent (Rashby et al., 2007). Stable isotopes can be a powerful means to track the rise of different physiological groups, provided the metabolisms in question utilize an element for which multiple stable isotopes exist and produce fractionations that are straightforward to interpret after diagenesis (Johnston et al., 2005). Genomics may also be helpful in inferring the evolution of different groups of organisms with particular metabolic functions, or the evolutionary history of specific enzymes, yet this approach operates on a relative temporal scale and may be confounded by horizontal gene transfer (House, 2007). Ultimately, contributions from all of these, and other, approaches will be necessary to paint a coherent picture of the metabolic evolution of early life.

In this note, we introduce a complimentary approach, 'palaeo-ecophysiology', to assess whether a particular metabolism might have been active during a given interval of Earth history. Ecophysiological approaches are commonly used in the field of microbial ecology, but to date,

Corresponding author: Dianne K. Newman, Tel.: 617-324-2770; fax: 617-324-3972; dkn@mit.edu.

Authors Croal and Jiao contributed equally to this work. 
have been applied only sparingly in geobiology. Modern ecophysiological studies attempt to assess the likelihood of the occurrence of a particular metabolism in a given environment by integrating what is known about particular variables in that environment with information on how these variables affect the metabolic processes of interest (Kopps \& Pommerening-Roser, 2001). 'Palaeo-ecophysiology' attempts the same, only it depends on limited geochemical data to infer the variables of interest, and assumes that modern microbes follow the same physiological rules as their ancient counterparts. These constraints aside, a palaeoecological approach has the potential to constrain, at least theoretically, the relevance of particular metabolisms to specific periods in Earth history. As an example, we consider the case of phototrophic Fe(II) oxidation in the Archean.

It has been suggested that anoxygenic photoautotrophs able to use ferrous iron [Fe(II)] as an electron donor for photosynthesis were involved in the deposition of banded iron formations (BIFs) that formed prior to the rise of $\mathrm{O}_{2}$ (Hartman, 1984; Widdel et al., 1993; Konhauser et al., 2002; Kopp et al., 2005). This model assumes that these bacteria used Fe(II) as an electron donor for photosynthesis. However, many anoxygenic phototrophs, including those able to oxidize $\mathrm{Fe}(\mathrm{II})$, are capable of using a variety of electron donors for photosynthetic growth. One such donor that is broadly used by diverse phototrophic bacteria is hydrogen gas $\left(\mathrm{H}_{2}\right)($ White, 1999).

The atmosphere of the early Earth is thought to have contained between 1000 and 300000 p.p.m. of $\mathrm{H}_{2}$ as a result of volcanic emissions and atmospheric photochemical reactions (Kasting, 1993; Catling et al., 2001; Tian et al., 2005). These quantities of $\mathrm{H}_{2}$ are sufficient to support $\mathrm{H}_{2}$-based photo-autotrophy, and it is therefore relevant to determine whether such quantities could have interfered with phototrophic Fe(II) oxidation. Coupling an understanding of the conditions under which phototrophic Fe(II) oxidation proceeds with bio-geochemical/ stratigraphic reconstructions of the ancient environment can help refine models that consider the role of these phototrophs in BIF deposition at different times in Earth history.

\section{$\mathrm{Fe}$ (II) oxidation still proceeds at significant rates in the presence of $\mathrm{H}_{\mathbf{2}}$}

To investigate the effects of the presence of $\mathrm{H}_{2}$ on phototrophic $\mathrm{Fe}(\mathrm{II})$ oxidation we studied Rhodopseudomonas palustris strain TIE-1 (Jiao et al., 2005) and Rhodobacter species strain SW2 (Widdel et al., 1993; Croal et al., 2007). Rates of Fe(II) oxidation in cell suspensions of these strains were measured under conditions where the concentrations of $\mathrm{Fe}(\mathrm{II})$, bicarbonate and $\mathrm{H}_{2}$ were comparable to those thought to be relevant for the Archean environment. We did not attempt to mimic other relevant aspects of the Archean ocean (e.g. silica content), as the experiments reported here grew out of work done in a growth medium routinely used for the cultivation of anoxygenic phototrophs. Specifically, the initial Fe(II) concentration of $\sim 0.5 \mathrm{mM}$ was within the upper range of $0.054-0.54 \mathrm{mM}$ predicted by Ewers (1983) and Holland (1973), the bicarbonate concentration of $20 \mathrm{mM}$ was on the same order as the $70 \mathrm{mM}$ predicted for an Archean ocean and an order of magnitude higher than the present-day concentration of $2 \mathrm{mM}$ (Grotzinger \& Kasting, 1993; Ohmoto et al., 2004) and the $\mathrm{H}_{2}$ concentration of 800000 p.p.m. was also on the same order as the recently proposed concentration in the prebiotic early atmosphere of 300000 p.p.m. (Tian et al., 2005). Recognizing that other organisms (such as methanogens) can consume $\mathrm{H}_{2}$, that methanogens are thought to be an ancient life form present in significant numbers early in Earth history (Ferry \& House, 2006), and that $\mathrm{CH}_{4}$ has been estimated to be as much as $10^{2}-10^{3}$ p.p.m. in the Archean atmosphere, the amount of $\mathrm{H}_{2}$ used in our studies is likely an over-estimate of what ancient phototrophs encountered.

Suspensions of TIE-1 and SW2 cells cultured phototrophically on $\mathrm{H}_{2}$ and harvested in early exponential phase $\left(\mathrm{OD}_{600} \sim 0.15-0.18\right)$ by centrifugation (RCF 12320 for $\left.20 \mathrm{~min}\right)$ were prepared for the $\mathrm{Fe}$ (II) oxidation assay in a COY anaerobic chamber. Pellets were washed once with an equal volume of $50 \mathrm{mM} \mathrm{N}$-2-hydroxyethylpiperazine-N'-2-ethanesulfonic acid 
(HEPES) buffer containing $20 \mathrm{mM} \mathrm{NaCl}$ at $\mathrm{pH} 7$ (assay buffer) and resuspended in $1 \mathrm{~mL}$ of assay buffer containing $0.5 \mathrm{mM} \mathrm{FeCl}_{2} \cdot \mathrm{H}_{2} \mathrm{O}$ and either $1 \mathrm{mM}$ or $20 \mathrm{mM} \mathrm{NaHCO} 3$ to a final OD600 of 1.0 in $12 \mathrm{~mL}$ sealed serum bottles. Resuspending the cells to the same final OD600 ensured that the assays were normalized to cell number, as verified by cell counts using a Petroff-Hauser counting chamber. The headspace of the assay bottles was then exchanged with either $\mathrm{N}_{2} / \mathrm{CO}_{2}\left(80: 20\right.$ [v/v]) or $\mathrm{H}_{2} / \mathrm{CO}_{2}(80: 20$ [v/v]) and assay bottles were shaken vigorously every $20 \mathrm{~min}$ during the assay to equilibrate the gas and liquid phases. Cell suspensions of TIE-1 and SW2 were incubated at $30^{\circ} \mathrm{C}$ and $16{ }^{\circ} \mathrm{C}$, respectively, $30 \mathrm{~cm}$ from a $34-\mathrm{W}$ tungsten incandescent light bulb and $\mathrm{Fe}$ (II) concentrations in the cell suspensions were measured by the ferrozine assay as described previously (Stookey, 1970; Croal et al., 2007).

When the bicarbonate concentration was low, in the absence of $\mathrm{H}_{2}$, the initial rates of $\mathrm{Fe}(\mathrm{II})$ oxidation for strains TIE- 1 and SW2 were $\sim 0.07 \mathrm{mM} \mathrm{h}^{-1}$ and $\sim 0.15 \mathrm{mM} \mathrm{h}^{-1}$, respectively (Fig. 1, Table 1). Under the same low bicarbonate conditions, in the presence of $\mathrm{H}_{2}$, the rate of $\mathrm{Fe}$ (II) oxidation by strain TIE- 1 decreased by $\sim 43 \%$ compared to its rate in the absence of $\mathrm{H}_{2} . \mathrm{Fe}$ (II) oxidation by strain SW2 was even more dramatically affected: during the first $5 \mathrm{~h}$ of the assay, the rate of $\mathrm{Fe}$ (II) oxidation by strain $\mathrm{SW} 2$ in the presence of $\mathrm{H}_{2}$ decreased by $\sim 80 \%$ as compared to the absence of $\mathrm{H}_{2}$. Furthermore, after $10 \mathrm{~h}$, only $\sim 22 \%$ of the total Fe(II) added initially was oxidized.

In contrast, in the presence of high concentrations of bicarbonate, while the rates of $\mathrm{Fe}$ (II) oxidation decreased for both strains in the presence of $\mathrm{H}_{2}$, their decrease was less dramatic as compared to the results in the presence of low bicarbonate. For strain TIE-1, the initial rate of $\mathrm{Fe}$ (II) oxidation decreased $\sim 31 \%$ as compared to that in the absence of $\mathrm{H}_{2}$, whereas for strain SW2, the initial rate of Fe(II) oxidation decreased $\sim 39 \%$ (Fig. 1A,B, Table 1). Under these conditions in the absence of $\mathrm{H}_{2}, \mathrm{SW} 2$ oxidized all of the Fe(II) within $2 \mathrm{~h}$, whereas TIE-1 took $8 \mathrm{~h}$, revealing a significant difference in their Fe(II) oxidation kinetics (Fig. 1A,B). This difference is consistent with the fact that these organisms have different enzymatic systems that control this process (Croal et al., 2007; Jiao \& Newman, 2007). In all cases, however, the observed decrease in the rate of $\mathrm{Fe}$ (II) oxidation in the presence of $\mathrm{H}_{2}$ was not due to $\mathrm{Fe}$ (III) reduction coupled to $\mathrm{H}_{2}$ oxidation: cell suspensions to which $1 \mathrm{mM}$ bicarbonate and $0.5 \mathrm{mM}$ ferric (hydr)oxide (synthesized according to the method of Schwertmann \& Cornell (1991)) were added did not produce detectable amounts of Fe(II) in the presence or absence of $\mathrm{H}_{2}$ as measured by the ferrozine assay (data not shown). The underlying cellular mechanism(s) whereby $\mathrm{H}_{2}$ inhibits $\mathrm{Fe}(\mathrm{II})$ oxidation (e.g. competition for electron acceptors in the electron transport chain, affects on production of key catalytic enzymes, etc.) await elucidation. Given that the extent of inhibition is sensitive to the bicarbonate concentration, we favour the hypothesis that when the terminal electron acceptor (e.g. $\left.\mathrm{CO}_{2}\right)$ is low, $\mathrm{H}_{2}$ may kinetically outcompete $\mathrm{Fe}(\mathrm{II})$ for oxidation by the electron transport chain.

Together, these results indicate that phototrophic Fe(II) oxidation may be affected by $\mathrm{H}_{2}$ in modern environments where the concentration of bicarbonate is low $(\sim 2 \mathrm{mM})$. However, if the concentration of bicarbonate is high (i.e. $>20 \mathrm{mM}$ ), as is predicted for the Archean ocean (Grotzinger \& Kasting, 1993; Ohmoto et al., 2004), even in an atmosphere containing 800000 p.p.m. $\mathrm{H}_{2}, \mathrm{Fe}$ (II) oxidation by these phototrophs could still have proceeded at appreciable rates.

\section{Implications for banded iron formations and metabolic evolution}

The implication of our results for BIF genesis is that when the physiological electron acceptor for photosynthesis $\left(\mathrm{CO}_{2}\right)$ is abundant (as is presumed to have been the case in an Archaean ocean), the presence of significant quantities of $\mathrm{H}_{2}$ in the atmosphere would not have precluded $\mathrm{Fe}(\mathrm{II})$ oxidation by anoxygenic phototrophs. The fact that the 'high' bicarbonate concentration used in our experiments $(20 \mathrm{mM})$ is lower than its estimated concentration in an Archean ocean 
by $\sim 3.5$-fold implies that the decrease in the $\mathrm{Fe}$ (II) oxidation rate reported here may overestimate the inhibition (if any) that would have occurred in the Archean.

The amount of $\mathrm{Fe}(\mathrm{III})$ minerals that could have been precipitated in an ancient ocean by anoxygenic phototrophs can be estimated using a rate of Fe(II) oxidation of $0.014 \mathrm{mM} \mathrm{Fe}$ (II) $\mathrm{day}^{-1}$ (Kappler et al., 2005). Higher rates of phototrophic Fe(II) oxidation have been published recently (Hegler et al., 2008), however, we chose the most conservative rate of $\mathrm{Fe}(\mathrm{II})$ oxidation for this calculation. Assuming an area equivalent to that covered by the Hamersley Basin in Western Australia [10 $11 \mathrm{~m}^{2}$ ] (Konhauser et al., 2002), $9.0 * 10^{12} \mathrm{~mol} \mathrm{Fe} \mathrm{year}^{-1}$ could have been oxidized and then precipitated by anoxygenic phototrophs. For organisms like SW2, the strain whose $\mathrm{Fe}(\mathrm{II})$ oxidation activity is most impacted by a $\mathrm{H}_{2}$ atmosphere (20\% relative to its rate in the absence of $\left.\mathrm{H}_{2}\right), 1.8 * 10^{12}$ mol Fe year $^{-1}$ could have been expected to be deposited. For organisms like strain TIE-1, which oxidizes Fe(II) more slowly than SW2 in the absence of $\mathrm{H}_{2}$ but is less affected by the presence of $\mathrm{H}_{2}(\sim 57 \%$ activity relative to its rate in the absence of $\mathrm{H}_{2}$ ), an iron deposition rate of $5.1 * 10^{12} \mathrm{~mol} \mathrm{Fe} \mathrm{year}^{-1}$ could have been expected. These rates of $\mathrm{Fe}$ (II) oxidation are both the same order of magnitude as the maximum rate necessary to deposit the Hamersley BIF $\left(4.5 * 10^{12} \mathrm{~mol} \mathrm{Fe} \mathrm{year}^{-1}\right.$; (Konhauser et al., 2002)). Moreover, these rates assume conditions where $\mathrm{H}_{2}$ has maximal effect. While these simple calculations are limited because they are based on experiments with only two strains and make an assumption about the baseline $\mathrm{Fe}$ (II) oxidation rate relevant for such organisms, to a first approximation, these 'palaeo-ecophysiological' studies support the plausibility of Fe(II)oxidizing phototrophs in the deposition of Archean BIFs in the presence of an atmosphere with an appreciable amount of $\mathrm{H}_{2}$.

Given that diffusion and $\mathrm{H}_{2}$ consumption rates by other bacteria are not considered in this calculation, we expect that the concentration of $\mathrm{H}_{2}$ would have been even lower within the photic zone inhabited by a community of ancient Fe(II)-oxidizing phototrophs. Additionally, the solubility of $\mathrm{H}_{2}$ in water decreases with increasing temperature (Fernandez-Prini et al., 2003). If estimations of Archean ocean temperatures at $70 \pm 15^{\circ} \mathrm{C}$ are correct (Knauth \& Lowe, 2003), the concentrations of $\mathrm{H}_{2}$ seen by SW2 and TIE- 1 in our experiments likely grossly overestimate the amount of $\mathrm{H}_{2}$ that would have been encountered by their ancient relatives. Therefore, it is likely that at depths approaching $100 \mathrm{~m}$ in an ancient ocean, $\mathrm{H}_{2}$ would have posed no barrier to Fe(II) oxidation. Moreover, in sulfide-depleted environments, which are thought to have prevailed in the ancient oceans prior to $1.8 \mathrm{Ga}$ (Poulton et al., 2004), $\mathrm{Fe}$ (II) may have been the predominant inorganic electron donor available for anoxygenic photosynthesis. Intriguingly, geochemical and stratigraphic data from the 3.4 Ga Buck Reef Chert suggest that the microbial communities active at this time were sustained by $\mathrm{H}_{2}$ as an electron donor rather than Fe(II) (Tice \& Lowe, 2004). This observation, when coupled to our finding that $\mathrm{H}_{2}$ would have posed no barrier to $\mathrm{Fe}(\mathrm{II})$ oxidation, suggests that the metabolic capacity for $\mathrm{Fe}$ (II) had not yet evolved at this time (assuming other factors essential for $\mathrm{Fe}$ (II) oxidation were not limiting). In this fashion, we can use the logic of palaeo-ecophysiology to constrain our dating of the rise of particular metabolisms.

\section{Acknowledgments}

We thank the reviewers for constructive comments and the members of the Newman laboratory for helpful discussion. This work was supported by grants from the Packard Foundation and Howard Hughes Medical Institute to D.K.N. and an NSF graduate fellowship to L.R.C.

\section{References}

Catling DC, Zahnle KJ, McKay C. Biogenic methane, hydrogen escape, and the irreversible oxidation of early Earth. Science 2001;293:839-843. [PubMed: 11486082] 
Croal LR, Jiao Y, Newman DK. The fox operon from Rhodobacter strain SW2 promotes phototrophic Fe (II) oxidation in Rhodobacter capsulatus SB1003. Journal of Bacteriology 2007;189:1774-1782. [PubMed: 17189371]

Ewers, WE. Chemical factors in the deposition and diagenesis of banded iron-formation. In: Trendall, AF.; Morris, RC., editors. Iron Formations: Facts and Problems. Elsevier; Amsterdam: 1983.

Fernandez-Prini R, Alvarez JL, Harvey AH. Henry's constants and vapor-liquid distribution constants for gaseous solutes in $\mathrm{H}_{2} \mathrm{O}$ and $\mathrm{D}_{2} \mathrm{O}$ at high temperatures. Journal of Physical and Chemical Reference Data 2003;32:903-916.

Ferry JG, House $\mathrm{CH}$. The stepwise evolution of early life driven by energy conservation. Molecular Biology and Evolution 2006;23:1286-1292. [PubMed: 16581941]

Grotzinger JP, Kasting JF. New constraints on Precambrian ocean composition. Journal of Geology 1993;101:235-243. [PubMed: 11537740]

Hartman, H. The evolution of photosynthesis and microbial mats: a speculation on banded iron formations. In: Cohen, Y.; Castenholz, RW.; Halvorson, HO., editors. Microbial Mats: Stromatolites. Alan. R. Liss; New York: 1984. p. 451-453.

Hegler F, Posth NR, Jiang J, Kappler A. Physiology of phototrophic iron(II)-oxidizing bacteria: implications for modern and ancient environments. FEMS Microbiological Ecology 2008;66:250260.

Holland HD. The oceans: a possible source of iron in iron-formations. Economic Geology 1973;68:11691172.

House CH. Linking taxonomy with environmental geochemistry and why it matters to the field of geobiology. Geobiology 2007;5:1-3.

Jiao Y, Newman DK. The pio operon is essential for phototrophic Fe(II) oxidation in Rhodopseudomonas palustris TIE-1. Journal of Bacteriology 2007;189:1765-1773. [PubMed: 17189359]

Jiao Y, Kappler A, Croal LR, Newman DK. Isolation and characterization of a genetically tractable photoautotrophic Fe(II)-oxidizing bacterium, Rhodopseudomonas palustris strain TIE-1. Applied and Environmental Microbiology 2005;71:4487-4496. [PubMed: 16085840]

Johnston DT, Wing BA, Farquhar J, Kaufman AJ, Strauss H, Lyons TW, Kah LC, Canfield DE. Active microbial sulfur disproportionation in the Mesoproterozoic. Science 2005;310:1477-1479. [PubMed: 16322453]

Kappler A, Pasquero C, Konhauser KO, Newman DK. Deposition of banded iron formations by anoxygenic phototrophic Fe(II)-oxidizing bacteria. Geology 2005;33:865-868.

Kasting JF. Earth's early atmosphere. Science 1993;259:920-926. [PubMed: 11536547]

Knauth LP, Lowe DR. High Archean climatic temperature inferred from oxygen isotope geochemistry of cherts in the $3.5 \mathrm{Ga}$ Swaziland Supergroup, South Africa. Geological Society of America Bulletin 2003; 115:566-580.

Konhauser KO, Hamade T, Raiswell R, Morris RC, Ferris FG, Southam G, Canfield DE. Could bacteria have formed the Precambrian banded iron formations? Geology 2002;30:1079-1082.

Kopp RE, Kirschvink JL, Hilburn IA, Nash CZ. The paleoproterozoic snowball Earth: a climate disaster triggered by the evolution of oxygenic photosynthesis. Proceedings of the National Academy of Sciences of the USA 2005;102:11131-11136. [PubMed: 16061801]

Kopps HP, Pommerening-Roser A. Distribution and ecophysiology of the nitrifying bacteria emphasizing cultured species. FEMS Microbiological Ecology 2001;37:1-9.

Ohmoto $\mathrm{H}$, Watanabe Y, Kumazawa K. Evidence from massive siderite beds for a $\mathrm{CO}_{2}$-rich atmosphere before $\sim 1.8$ billion years ago. Nature 2004;429:395-399. [PubMed: 15164058]

Poulton SW, Fralick PW, Canfield DE. The transition to a sulphidic ocean $\sim 1.84$ billion years ago. Nature 2004;431:173-177. [PubMed: 15356628]

Rashby SE, Sessions AL, Summons RE, Newman DK. Biosynthesis of 2-methylbacteriohopanepolyols by an anoxygenic phototroph. Proceedings of the National Academy of Sciences of the USA 2007;104:15099-15104. [PubMed: 17848515]

Schwertmann, U.; Cornell, RM. Iron Oxides in the Laboratory: Preparation and Characterization. VCH Publishers; Weinheim, Germany: 1991. 
Stookey LL. Ferrozine - a new spectrophotometric reagent for iron. Analytical Chemistry 1970;42:779_ 781.

Tian F, Toon OB, Pavlov AA, De Sterck H. A hydrogen-rich early Earth atmosphere. Science 2005;308:1014-1017. [PubMed: 15817816]

Tice MM, Lowe DR. Photosynthetic microbial mats in the 3416-Myr-old ocean. Nature 2004;431:549_ 552. [PubMed: 15457255]

White, D. The Physiology and Biochemistry of Prokaryotes. Oxford University Press; Oxford, UK: 1999.

Widdel F, Schnell S, Heising S, Ehrenreich A, Assmus B, Schink B. Ferrous iron oxidation by anoxygenic phototrophic bacteria. Nature 1993;362:834-836. 

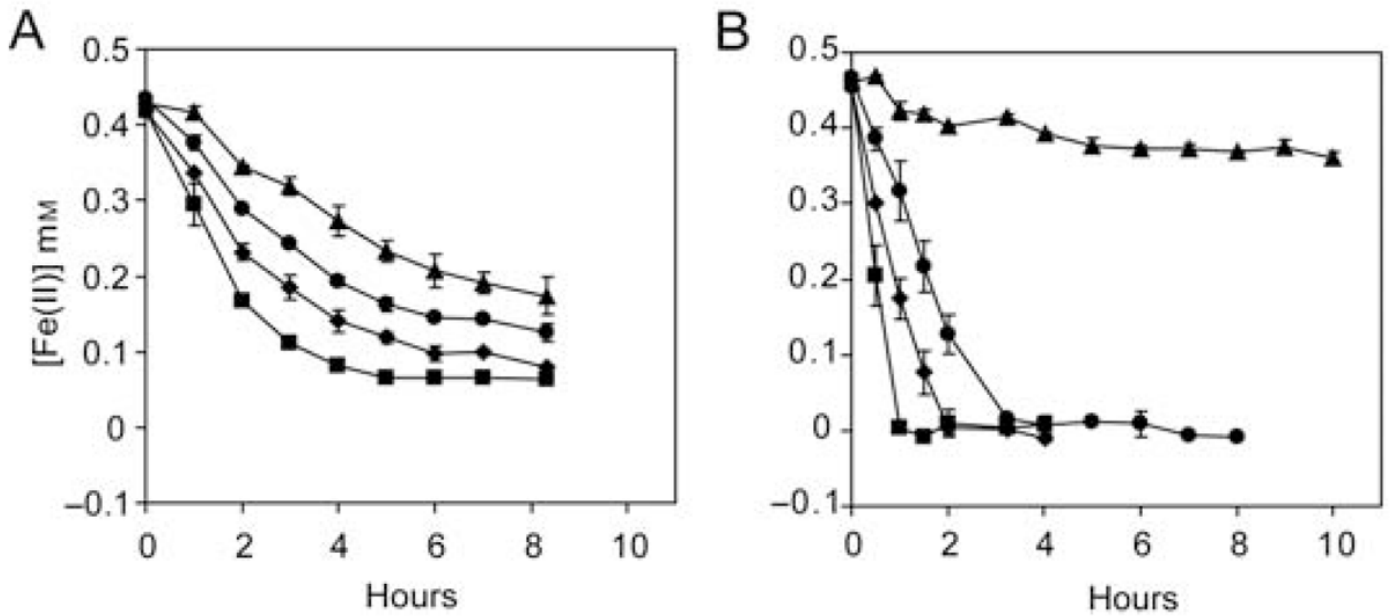

Fig. 1.

The effect of $\mathrm{H}_{2}$ on the $\mathrm{Fe}$ (II) oxidation activity of strains TIE-1 (A) and SW2 (B) varies depending on the concentration of $\mathrm{NaHCO}_{3} \cdot \mathbf{\Delta}: \mathrm{H}_{2}+1 \mathrm{mM} \mathrm{NaHCO}_{3} ; \bullet: \mathrm{N}_{2}+1 \mathrm{mM}$ $\mathrm{NaHCO}_{3} ; \mathrm{H}_{2}+20 \mathrm{mM} \mathrm{NaHCO}_{3} ; \boldsymbol{m}: \mathrm{N}_{2}+20 \mathrm{mM} \mathrm{NaHCO}_{3}$. Data are representative of two independent experiments. Error bars represent the error on duplicate cell suspension assays for strain TIE-1 and triplicate assays for strain SW2. 
Table 1

Comparison of the Fe(II) oxidation rates for strains TIE-1 and SW2 under low bicarbonate (1 mM) and high bicarbonate (20 $\mathrm{mM}$ ) concentrations in the presence or absence of $\mathrm{H}_{2}$. Rates were calculated using the first three time points for all conditions in Fig. 1 except for strain SW2 under low bicarbonate concentrations in the presence of $\mathrm{H}_{2}$; here the first five time points were considered

\begin{tabular}{|c|c|c|c|c|}
\hline \multirow[b]{3}{*}{ Strain } & \multicolumn{2}{|c|}{ Low $\mathrm{NaHCO}_{3}$} & \multicolumn{2}{|c|}{ High $\mathrm{NaHCO}_{3}$} \\
\hline & $+\mathrm{H}_{2}$ & $-\mathbf{H}_{2}$ & $+\mathrm{H}_{2}$ & $-\mathbf{H}_{2}$ \\
\hline & \multicolumn{2}{|c|}{$\overline{\left(\mathrm{mM} \mathrm{Fe}(\mathrm{II}) \text { oxidized } \mathrm{h}^{-1}\right)}$} & \multicolumn{2}{|c|}{$\left(\mathrm{mM} F e(I I)\right.$ oxidized h$\left.^{-1}\right)$} \\
\hline $\begin{array}{l}\text { TIE-1 } \\
\text { SW2 }\end{array}$ & $\begin{array}{l}0.04 \\
0.03\end{array}$ & $\begin{array}{l}0.07 \\
0.15\end{array}$ & $\begin{array}{l}0.09 \\
0.28\end{array}$ & $\begin{array}{l}0.13 \\
0.46\end{array}$ \\
\hline
\end{tabular}

